\title{
Perancangan Penstock (Pipa Pesat) Untuk Pembangkit Listrik Tenaga Mikrohidro ( PLTMH ) Di Banjar Dinas Mekarsari, Desa Panji, Kecamatan Sukasada, Kabupaten Buleleng
}

\author{
I Nengah Widiana ${ }^{1}$, Ida Ayu Dwi Giriantari ${ }^{2}$,I Nyoman Setiawan ${ }^{3}$ \\ [Submission: 08-11-2020, Accepted: 29-11-2020]
}

\begin{abstract}
Since 1980, Banjar Dinas Mekar Sari, Panji Village has had a Micro Hydro Power Plant (PLTMH). PLTMH which has a generating capacity of $10 \mathrm{~kW}$ experiences various problems resulting in improper operation. One of the proposed improvements is a penstock (fast pipe) design in accordance with the PLTMH Banjar Dinas Mekar Sari. The new penstock design resulted in a penstock that was 54 meters long, a penstock diameter of 0.8272 meters, and a penstock thickness of 0.002 meters. The flow velocity on the penstock after the new design was $2.7088 \mathrm{~m} / \mathrm{s}$, and the net head was 16 meters. This improvement is intended to take full advantage of the height of the river flow so that a maximum flow rate can be generated which is then used to turn the turbine.
\end{abstract}

Keyword- Renewable energy, PLTMH, Micro hydro, Penstock

Sejak tahun 1980 banjar dinas Mekar Sari Desa Panji telah memiliki Pembangkit Listrik Tenaga Mikrohidro (PLTMH). PLTMH yang memiliki kapasitas pembangkitan $10 \mathrm{~kW}$ ini mengalami berbagai permasalahan yang mengakibatkan operasinya yang tidak sesuai. Salah satu perbaikan yang diusulkan adalah perancangan penstock (pipa pesat) yang sesuai dengan PLTMH banjar dinas Mekar Sari. Perancangan penstock yang baru menghasilkan penstock dengan panjang 54 meter, diameter penstock 0,8272 meter dan tebal penstock sebesar 0,002 meter. Untuk kecepatan aliran pada penstock setelah di rancang baru adalah $2,7088 \mathrm{~m} / \mathrm{s}$, dan head bersih adalah 16 meter. Perbaikan ini dimaksudkan untuk memanfaatkan tinggi aliran sungai secara maksimal, sehingga kecepatan aliran dapat dihasilkan maksimal untuk selanjutnya digunakan memutar turbin.

Kata kunci- Energi terbarukan, PLTMH, mikrohidro, penstock

\footnotetext{
${ }^{1}$ Mahasiswa,Program Studi Teknik Elektro Fakultas Teknik Universitas Udayana, Jalan Bhuana Raya no 103,Denpasar 80117. Indonesia (telp:085792176110;e-mail:widiananengah97@gmail.com)

${ }^{2,3}$ Dosen,Program Studi Teknik Elektro Fakultas Teknik Universitas Udayana, Jln. Jalan Kampus Bukit Jimbaran 80361 INDONESIA (telp: 0361-703315; fax: 0361-4321; e-mail: 22dayu.giriantari@unud.ac.id, setiawan@unud.ac.id)
}

\section{PENDAHULUAN}

Indonesia memiliki sumber daya alam yang melimpah, salah satunya adalah aliran sungai yang dapat dimanfaatkan sebagai pembangkit tenaga listrik. Potensi energi mini-micro hydro di Indonesia adalah sebesar 19.385 MW dan 30 MW diantaranya terdapat di Bali, sedangkan pemanfaatannya hanya 197,4 MW, sekitar 1\% dari potensi [1]. Pembangkit Listrik Tenaga Mikrohidro (PLTMH) adalah sebuah pembangkit listrik dengan pembangkitan listrik berskala kecil yang menggerakan turbin dengan memanfaatkan tinggi terjunan dan jumlah debit aliran kecil seperti irigasi atau sungai. Pembangkit listrik dengan energi terbarukan masih rendah pada 2012 yaitu 11,31\% dari produksi energi total. Pemanfaatan energi air dimulai dari tahun 1970, namun belum sering digunakan. [2].

Banjar Dinas Mekarsari, Desa Panji, Kecamatan Sukasada, Kabupaten Bueleleng adalah salah satu banjar dinas yang sudah menfaatkan energi air dari tahun 1980 sampai sekarang. Namun, dari tahun ke tahun pembangkitan energi listrik pada PLTMH Banjar Dinas Mekarsari terus mengalami penurunan. Pada tahun 2019 PLTMH Banjar Dinas Mekarsari membangkitkan energi listrik sebesar $200 \mathrm{~W}$ dari $10 \mathrm{~kW}$ yang dapat dibangkitkan oleh generator PLTMH Banjar Dinas Mekarsari. Hal tersebut terjadi karena komponen-komponen PLTMH Banjar Dinas Mekarsari telah rusak akibat tidak adanya pemeliharaan komponen secara berkala, PLTMH Mekar Sari juga dirancang tanpa melalui analisa teknis saat pembuatan PLTMH Banjar Dinas Mekarsari. Salah satu faktor penyebab menurunnya pembangkitan dari PLTMH Banjar Dinas Mekarsari adalah pemanfaatan tinggi aliran sungai yang dialirkan melalui penstock kurang maksimal. Saat ini panjang penstock di PLTMH Mekarsari kurang dari 5 meter. Berdasarkan keterbatasan diatas maka diperlukan desain ulang PLTMH yang beroperasi di Banjar Dinas Mekar Sari, Desa Panji, Kecamatan Sukasada, Buleleng.

Untuk mengatasi permasalahan, di dalam penelitian ini akan dilakukan perancangan ulang desain PLTMH untuk memanfaatkan aliran air pada Tukad Pasut secara optimal. Artikel ini membahas perancangan penstock PLTMH Mekar Sari berdasarkan data potensi di lokasi.

\section{KAJIAN PUSTAKA}

A. Pembangkit Listrik Tenaga Mikrohindro (PLTMH)

p-ISSN:1693 - 2951; e-ISSN: 2503-2372 
PLTMH adalah penggunaan tenaga air untuk membangkitkan listrik dalam ukuran kecil (5 - $100 \mathrm{~kW})$. Mikrohidro diartikan sebagai daya kurang dari $100 \mathrm{~kW}$ dan daya antara $100 \mathrm{~kW}$ sampai $5000 \mathrm{~kW}$ disebut minihidro [3].

PLTMH jenis run-off, tanpa pembangun bendungan besar, namun aliran sungai ke salah satu sisi dapat dialihkan dan mengembalikan aliran air ke kesebelumnya setelah aliran air yang diperlukan untuk pembangkitan telah didapatkan. Air berfungsi untuk menggerakan turbin melalui pipa pesat. PLTMH menggunakan tinggi terjunan dan kapasitas debit aliran air. Kemudian poros turbin berputar dengan memanfaatkan aliran air sehingga menghasilkan energi listrik[4]. Pada prinsipnya PLTMH bekerja dengan cara mengubah energi potensi air menjadi energi listrik[5].

\section{B. Penstock}

Penstock ialah pipa yang dialiri air bertekanan dari bak penampungan ke turbin[6]. Penstock dapat juga disebut dengan pipa bertekanan[7].

\section{Bahan Penstock}

Bahan yang berasal dari bambu dan kayu dapat dimanfaatkan sebagai bahan alami.

Baja, UPVC, HDPE, GRP dan beton merupakan bahan buatan yang dapat digunakan sebagai pipa pesat [8].

\section{Katup}

Katup ialah komponen penstock sebagai pengontrol aliran air. Contohnya adalah, butterfly valve, ball valve, globe valve, pilot valve, dan gate valve [9]. Katup umumnya berada di saluran inlet dan saluran inlet turbin.

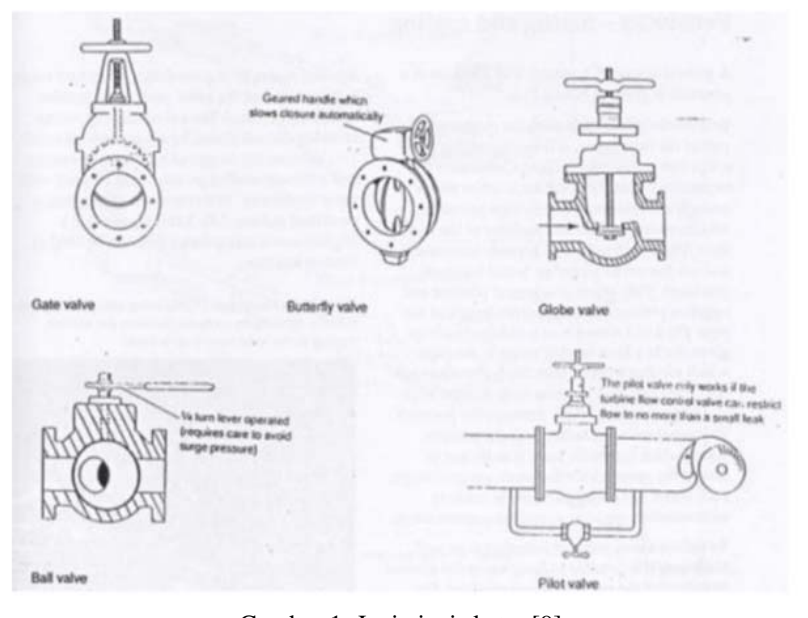

Gambar 1: Jenis-jenis katup[9]

E. Perancangan Penstock

Perancangan Penstock PLTMH menggunakan persamaan sebagai berikut[9].

1. Diameter Penstock (d)[9]

$d=0,72 \cdot Q^{0,5}$

Dimana :

$$
\begin{array}{ll}
\mathrm{d} & =\text { Diameter penstock }(\mathrm{m}) \\
\mathrm{Q} & =\text { Debit }\left(\mathrm{m}^{\mathbf{3}} / \mathrm{s}\right)
\end{array}
$$

2. Tebal Penstock (t) [9]

$$
t=\frac{(p \times g \times H) \times r \times 1000}{q}
$$

Dimana :

$\mathrm{p}=$ Massa jenis air $\left(\operatorname{ton} / \mathrm{m}^{3}\right)$

g = Percepatan gravitasi $\left(9,8 \mathrm{~m} / \mathrm{s}^{2}\right)$

$\mathrm{H} \quad=$ Tinggi $(\mathrm{m})$

$\mathrm{r} \quad=\mathrm{Jari}-\mathrm{j}$ ari penstock $(\mathrm{m})$

q $\quad=$ Tegangan material pipa (ton $/ \mathrm{m}^{3}$ )

3. Kecepatan Aliran Pada Penstock (v) [9]

$v=\frac{4 \cdot Q}{\pi \cdot d^{2}}$

Dimana :

$\mathrm{v}=$ Kecepatan aliran $(\mathrm{m} / \mathrm{s})$

$\mathrm{d}=$ Diameter penstock $(\mathrm{m})$

4. Menghitung $\mathrm{h}_{\text {friction }}\left(\mathrm{h}_{\text {friction }}\right)$ [9]

$h_{\text {friction }}=h_{\text {wall loss }}+h_{\text {turò loss }}$

Dimana

$\mathrm{h}_{\text {friction }}=$ Rugigesekan $(\mathrm{m})$

$h_{\text {walloss }}=$ Rugi pada dinding penstock $(\mathrm{m})$

$h_{\text {turnloss }}=$ Rugi pada aliran turbulensi $(\mathrm{m})$

5. Menghitung $h_{\text {wall loss }}$ [9]

$h_{\text {wall loss }}=\frac{f \text {.lpipe } .0,0 \Omega \cdot Q^{2}}{d^{5}}$

Dimana

$\mathrm{Q}=$ Debit $\left(\mathrm{m}^{3} / \mathrm{s}\right)$

$\mathrm{L}=$ Panjang penstock $(\mathrm{m})$

$\mathrm{d}=$ Diameter $(\mathrm{m})$

$\mathrm{f}=$ Konstanta friksi

6. Menghitung $\mathrm{Head}_{\text {net }}[9]$

$H_{\text {net }}=H_{\text {gross }}+h_{\text {frictions }}$

7. Mengitung $\mathrm{h}_{\text {turb loss }}[9]$

$h_{\text {turo loss }}=\frac{v^{2}}{2 g}\left(K_{\text {entrance }}+K_{\text {bend }}+\right.$

$\left.K_{\text {contraction }}+\cdots K_{\text {valve }}\right)$

Dimana :

$\checkmark \quad=$ Kecepatan aliran $(\mathrm{m} / \mathrm{s})$

g = Gaya gravitasi $\left(\mathrm{m} / \mathrm{s}^{2}\right)$

8. Penghitungan $h_{\text {surge }}$ dan Kecepatan Rambat Gelombang (a) [9]

$h_{\text {surge }}=\frac{a \cdot v}{g}$

Dimana

$\mathrm{V} \quad=$ Kecepatan $\operatorname{aliran}(\mathrm{m} / \mathrm{s})$

g = Gaya gravitasi $\left(\mathrm{m} / \mathrm{s}^{2}\right)$

$a=\frac{1400}{\sqrt{1+\left(\frac{2,1 \times 10^{9} \times d}{E x t}\right)}}$

9. Penghitungan Safety Factor (SF) [9]

$S F=\frac{t \times s}{s \times \text { htotal } x 10^{5} x d}$

Dimana

SF $\quad=$ Safety factor

$\mathrm{t} \quad=$ tebal penstock $(\mathrm{m})$

$\mathrm{S} \quad=$ kekuatan $\operatorname{Bahan}\left(\mathrm{N} / \mathrm{m}_{2}\right)$

$\mathrm{d}=\operatorname{diameter}(\mathrm{m})$

$\mathrm{h}_{\text {total }} \quad=$ rugi-rugi total $(\mathrm{m})$

F. Expansion Joint 
Expansion joint adalah sambungan yang didesain akibat adanya pemuaian pada pipa pesat sehingga menyebabkan perubahan panjang disetiap ujung pada pipa pesat[10]. Fungsi expansion joint ialah untuk menahan gesekan pada saat air dialirkan[11][12],[13],[14],[15]

Berikut adalah rumus expansiom joint[9].

$\mathrm{X}=\mathrm{a}(\mathrm{Thot}-\mathrm{T}$ cold $) \mathrm{L}[\mathrm{m}]$

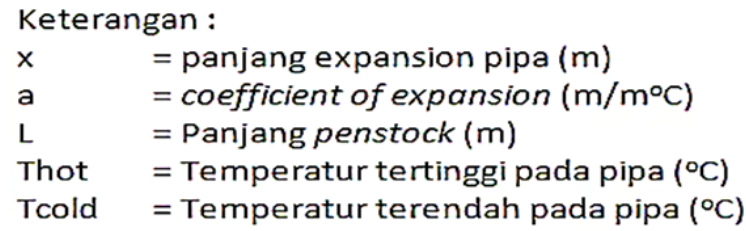

\section{Metodologi Penelitian}

Penelitian di awali dengan indentifikasi lokasi penelitian untuk mengetahui lokasi dari PLTMH dan kondisi terkini dari PLTMH[16][17],[18],[19],[20].Mekar Sari serta letak geografisnya menggunakan Google Earth.

Langkah selanjutnya adalah pengumpulan debit air yang dimanfaatkan yang diketahui $1,32 \mathrm{~m}^{3} /$ detik yang didapatkan dari Balai Wilayah Sungai Bali-Penida. Dari hasil observasi terakhir diperoleh bahwa kondisi debit tidak banyak berubah. Panjang penstock dapat diketahui menggunakan Google Earth

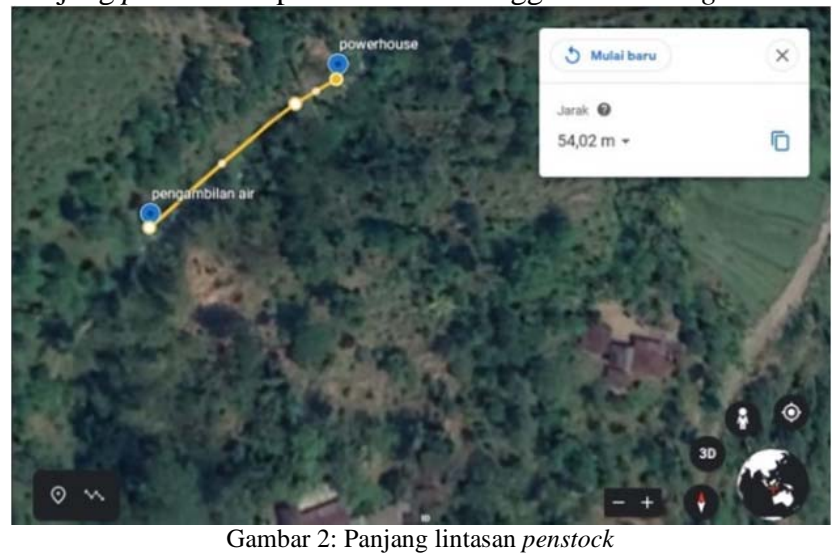

Selain itu, setelah mengetahui debit sungai, maka diameter pesntock dapat dihitung menggunakan persamaan 1 . Selanjutnya tebal penstock dapat dihitung dengan persamaan 2. Ditentukannya jumlah katup dan jenis katup penstock, jumlah anchor block dan slide block dalam mempertahakan guncangan yang disebabkan oleh gaya-gaya pada penstock agar tetap pada posisinya sehingga penstock tidak mengalami pergeseran.

Setelah digambar sesuai dengan data perancangan, maka dilakukan perhitungan kecepatan aliran di dalam penstock, seperti rugi-rugi gesekan, rugi-rugi turbulensi, rugi-rugi total yang terjadi, persentase kehilangan head, surger pressure, safety factor, expansion joint yang berfungsi untuk mengetahui tebal bahan yang digunakan untuk meredam gerakan yang diakibatkan dari perubahan suhu akibat gesekan air dalam penstock dan beban air dalam penstock yang bergerak

I Nengah Widiana : Perancangan Penstock (Pipa Pesat)...

\section{HASIL DAN PEMBAHASAN}

Listrik yang ada di Desa Panji di pasok melalui penyulang Panji, namun untuk daerah selatan Desa Panji belum semua teraliri listrik dikarenakan akses jalan yang belum memadai. Jarak terdekat untuk mencapai jaringan listrik PLN adalah 1 km. Lokasi Desa Panji dapat dilihat pada Gambar 3.

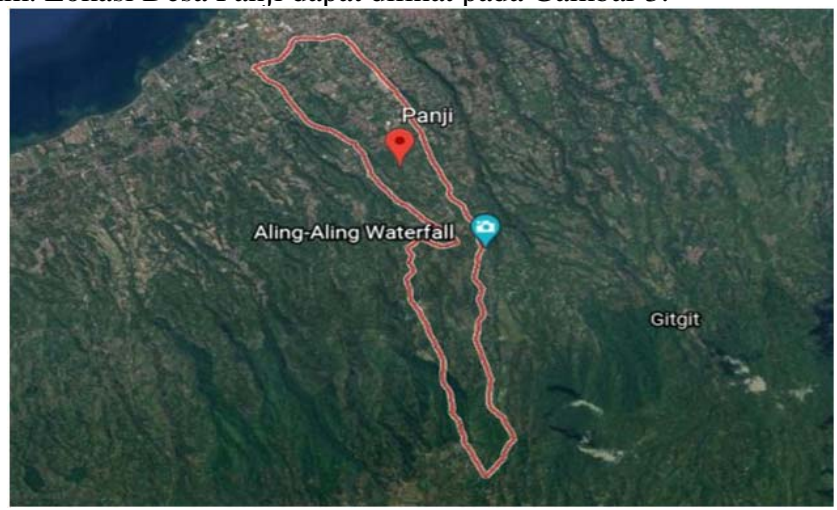

Gambar 3: Lokasi Desa Panji (Google Eartth)

PLTMH Mekar Sari adalah sebuah pembangkit yang dibangun pada tahun 1980 dan digunakan sebagai sumber tenaga listrik oleh masyarakat di Desa Panji. Namun sejak tahun 2019, PLTMH ini sudah tidak beroperasi lagi karena sudah tua dan banyak komponennya yang rusak. Sungai yang dimanfaatkan untuk PLTMH adalah sungai atau Tukad Pasut. Gambar 5 menunjukkan kondisi sungai Pasut dan turbin PLTMH Mekar Sari.

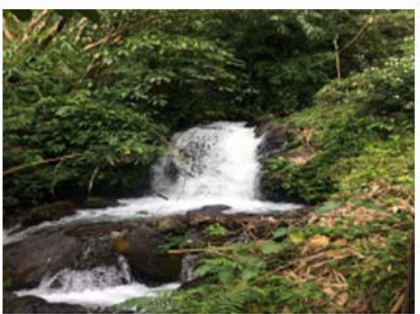

(a) Sungai Pasut

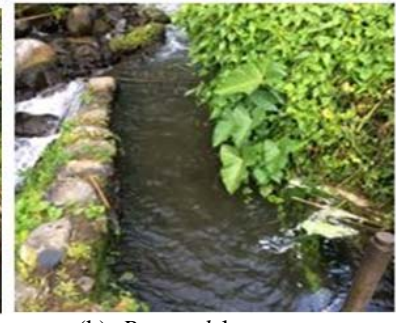

(b) Penstock lama Gambar 4: Kondisi sungai dan penstock PLTMH Mekar Sari

PLTMH Mekar Sari terdiri dari bak penenang, governor, penstok, turbin air, pully, generator, instalasi listrik sederhana, dan saluran pembuangan. Untuk lebih jelas bisa dilihat pada Gambar 5.

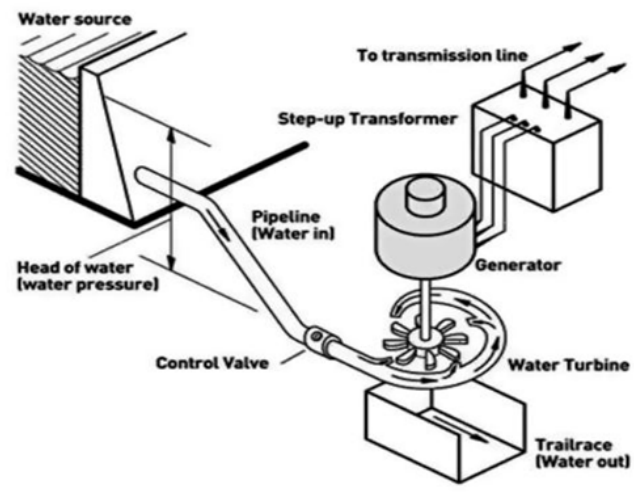

Gambar 5: Skematik PLTMH Mekar Sari[12]

p-ISSN:1693 - 2951; e-ISSN: 2503-2372 
Redesain PLTMH yang ada di Banjar Dinas Mekar Sari, Desa Panji memanfaatkan aliran sungai Tukad Pasut yang yang memiliki debit terkecil $1.32 \mathrm{~m}^{3} /$ detik. Head net yang didapatkan adalah $16 \mathrm{~m}$ dengan panjang penstock 54,02 m. Power House yang digunakan adalah yang power house yang sudah ada sebelumnya. Perancangan turbin secara lengkap akan dijelaskan di bawah ini.

\section{A. Diameter Penstock}

Diamater penstock dipengaruhi oleh debit air yang di manfaatkan. Perhitungan diameter penstock menggunakan persamaan 2 sebagai berikut.

$$
\begin{aligned}
\mathrm{d} & =0,72 \cdot \mathrm{Q}_{\mathrm{d}}^{0,5} \\
& =0,72 \cdot 1,32^{0,5} \mathrm{~m}^{3} / \mathrm{s} \\
& =0,72 \cdot 1,1489 \mathrm{~m}^{3} / \mathrm{s} \\
& =0,8272 \mathrm{~m}
\end{aligned}
$$

B. Tebal Penstock

Tebal penstock dapat di hitung menggunakan Persamaan 2.

$\mathrm{t}=\frac{(0,997 \times 9,8 \times 17) \times 0,4136 \times 1000}{35126,397}$

$\mathrm{t}=\frac{(166,10) \times 0,4136 \times 1000}{35126,397}$

$t=\frac{68,7}{35126,397}$

$\mathrm{t}=0,00195 \mathrm{~m}$

$\mathrm{t}=1,95 \mathrm{~mm}$

$\mathrm{t}=2 \mathrm{~mm}$

C. Bahan Penstock

Mild Steel Galvanized (Baja berlapis) ialah bahan yang digunakan sebab dapat menahan tekanan yang terjadi sewaktu-waktu pada penstock.

D. Sambungan dan Jumlah Belokan Penstock

Perancangan penstock ini memanfaatkan sambungan pengelasan, sebab harga yang murah daripada dengan yang lain serta menyesuaikan dengan letak penstock yang akan dibangun.

Sesuai dengan gambar 2, karena pada perancangan penstock ini mengikuti kontur atau topografi dari daerah alirah sungai sehingga jumlah belokan pada lintasan penstock terdapat 2 buah belokan.

E. Katup dan Jumlah Anchor dan Support Block

Pada rancangan ini didapatkan bahwa penstock menggunakan pada inlet penstock ialah gate valve dan butterfly valve pada outlet penstock.

Berdasarkan panjang lintasan pada gambar 2, maka jumlah anchor block sebanyak 3 buah.

Kebutuhan slide block adalah 11 buah.

F. Kecepatan Aliran

Kecepatan aliran pada penstock dapat dihitung menggunakan persamaan 3 .

$$
\begin{aligned}
& v=\frac{4 \cdot Q}{\pi \cdot d^{2}} \\
& v=\frac{4 \cdot 1,32}{3,14 \cdot 0,8272^{2}}
\end{aligned}
$$

$$
\begin{aligned}
v & =\frac{5,82}{2,1485} \\
v & =2,7088 \mathrm{~m} / \mathrm{s}
\end{aligned}
$$

G. Rugi-rugi padaPenstock

1. Rugi-rugi gesekan pada dinding pestock

Dapat dihitung dengan menggunakan persamaan 5.

$$
\begin{aligned}
& h_{\text {wall loss }}=\frac{f \cdot L \cdot 0,08 \cdot Q^{2}}{d^{5}} \\
& h_{\text {wall loss }}=\frac{0,038 \cdot 54 \cdot 0,08 \cdot 1 \cdot 32^{2}}{0,8272^{5}} \\
& h_{\text {wall loss }}=\frac{0,038 \cdot 54 \cdot 0,08 \cdot 1,7424}{0,3873} \\
& h_{\text {wall loss }}=\frac{0,2860}{0,3873} \\
& h_{\text {wall loss }}=0,7385 \mathrm{~m}
\end{aligned}
$$

2. Rugi-rugi Turbulensi pada Penstock

Dapat dihitung dengan menggunakan persamaan 7.

$$
\begin{aligned}
\mathrm{h}_{\text {tub loss }} & =\frac{\mathrm{V}^{2}}{2 \cdot \mathrm{g}}\left(\mathrm{K}_{\text {entrance }}+\mathrm{K}_{\text {Bend }}+\mathrm{K}_{\text {valve }}\right) \\
\mathrm{h}_{\text {tub loss }} & =\frac{2,7088^{2}}{2 \cdot 9,8}(0,805) \\
\mathrm{h}_{\text {tub loss }} & =\frac{7,3375}{19,6}(0,805) \\
\mathrm{h}_{\text {tub loss }} & =0,3734(0,805) \\
\mathrm{h}_{\text {tub loss }} & =0,3005 \mathrm{~m}
\end{aligned}
$$

3. Rugi-rugi Friction

Dapat dihitung dengan menggunakan persamaan 4.

$$
\begin{aligned}
& h_{\text {friction }}=h_{\text {wall loss }}+h_{\text {tub loss }} \\
& h_{\text {friction }}=0,7385+0,3005 \\
& h_{\text {friction }}=1,039 \mathrm{~m}
\end{aligned}
$$

H. Head $_{\text {net }}$

Head $_{\text {net }}$ dapat dihitung dengan menggunakan persamaan 6 . $H_{\text {gross }}=17 \mathrm{~m}$

$H_{\text {net }}=H_{\text {gross }}-h_{\text {friction }}$

$H_{\text {net }}=17-1,039$

$H_{\text {net }}=15,961 \mathrm{~m}$

Hasil $\mathrm{H}_{\text {net }}$ adalah 15,961 m dikonversi menjadi $16 \mathrm{~m}$. Kemudian hitung persentase losses, maka didapatkan.

$$
\begin{aligned}
\% \text { Losses } & =\frac{h_{\text {friction }}}{H_{\text {gross }}} \times 100 \% \\
\% \text { Losses } & =\frac{1,039}{17} \times 100 \% \\
\% \text { Losses } & =0,061 \times 100 \% \\
\% \text { Losses } & =6,1 \%
\end{aligned}
$$

I. Surge Pressure

Menentukan pressure wave velocity:

$$
a=\frac{1400}{\sqrt{1+\left(\frac{2,1 \times 10^{9} \times d}{E \times t}\right)}}
$$




$$
\begin{aligned}
& a=\frac{1400}{\sqrt{1+\left(\frac{2,1 \times 10^{9} \times 0,8272}{200 \times 10^{9} \times 2}\right)}} \\
& a=\frac{1400}{\sqrt{1+\left(\frac{1,73712}{0,4}\right)}} \\
& a=\frac{1400}{\sqrt{1+(4,3428)}} \\
& a=\frac{1400}{\sqrt{5,3428}} \\
& a=\frac{1400}{2,3114} \\
& a=605,7 \mathrm{~m} / \mathrm{s}
\end{aligned}
$$

Menggunakan persamaan Surge pressure

$$
\begin{aligned}
& h_{\text {surge }}=\frac{a \cdot v}{g} \\
& h_{\text {surge }}=\frac{605,7 \cdot 2,7088}{9,8} \\
& h_{\text {surge }}=167,42 \mathrm{~m}
\end{aligned}
$$

J. Rugi-rugi Total

Rugi-rugi total dapat dihitung dengan menggunakan persamaan.

$$
\begin{aligned}
& h_{\text {total }}=H_{\text {gross }}+h_{\text {surge }} \\
& h_{\text {total }}=17+167,42 \\
& h_{\text {total }}=184,42 \mathrm{~m}
\end{aligned}
$$

K. Safety Factor

Safety factor dapat dihitung dengan menggunakan

\begin{tabular}{|c|c|c|c|}
\hline No & \multicolumn{2}{|c|}{ Data Perhitungan } & $\begin{array}{c}\text { Hasil } \\
\text { Perhitungan }\end{array}$ \\
\hline 1 & \multicolumn{2}{|c|}{ Kecepatan Aliran } & $2,7088 \mathrm{~m} / \mathrm{s}$ \\
\hline 2 & \multicolumn{2}{|c|}{$\begin{array}{l}\text { Rugi-rugi pada dinding } \\
\text { penstock }\end{array}$} & $0,7385 \mathrm{~m}$ \\
\hline 3 & \multicolumn{2}{|c|}{ Rugi-rugi turbulensi } & $0,3005 \mathrm{~m}$ \\
\hline 4 & \multicolumn{2}{|c|}{ Rugi-rugi gesekan } & $1,039 \mathrm{~m}$ \\
\hline 5 & \multicolumn{2}{|c|}{ Head $_{\text {gross }}$} & $17 \mathrm{~m}$ \\
\hline 6 & \multicolumn{2}{|c|}{ Head $_{\text {net }}$} & $16 \mathrm{~m}$ \\
\hline 7 & \multicolumn{2}{|c|}{$\begin{array}{l}\text { Persentase kehilangan } \\
\text { Head akibat rugi-rugi }\end{array}$} & $6,1 \%$ \\
\hline 8 & \multicolumn{2}{|c|}{ Surge pressure } & $167,42 \mathrm{~m}$ \\
\hline 9 & \multicolumn{2}{|c|}{ Rugi-rugi total } & $184,42 \mathrm{~m}$ \\
\hline 10 & \multicolumn{2}{|c|}{ Safety Factor } & 1 \\
\hline \multirow[t]{2}{*}{11} & \multirow{2}{*}{$\begin{array}{l}\text { Expansion } \\
\text { joint }\end{array}$} & L1 $(43 \mathrm{~m})$ & $7,74 \mathrm{~mm}$ \\
\hline & & $\mathrm{L} 2(11 \mathrm{~m})$ & $1,98 \mathrm{~mm}$ \\
\hline \multirow[t]{2}{*}{12} & \multirow[t]{2}{*}{$\begin{array}{c}\text { Gaya pada } \\
\text { Anchor block }\end{array}$} & $\begin{array}{c}q w \\
\text { (water) }\end{array}$ & $5262 \mathrm{~N} / \mathrm{m}$ \\
\hline & & qp (steel) & $\begin{array}{c}107214,76 \\
\mathrm{~N} / \mathrm{m}\end{array}$ \\
\hline \multirow[t]{2}{*}{13} & \multirow{2}{*}{$\begin{array}{l}\text { Gaya pada } \\
\text { slide block }\end{array}$} & F1 & $12890 \mathrm{~N}$ \\
\hline & & F2 & $6445,27 \mathrm{~N}$ \\
\hline
\end{tabular}
persamaan 10 .

$$
\begin{aligned}
S F & =\frac{t \times S}{5 \times h_{\text {total }} \times 10^{3} \times d} \\
S F & =\frac{0,002 \times 350000000}{5 \times 184,42 \times 10^{3} \times 0,8272} \\
S F & =\frac{700}{765,9} \\
S F & =0,9 \\
S F & =1
\end{aligned}
$$

L. Urain hasil perhitungan

Uraian hasil perhitungan untuk perancangan penstock.
TABEL I

URAIAN PERANCANGAN PENSTOCK

\begin{tabular}{|c|c|c|}
\hline No. & $\begin{array}{c}\text { Uraian } \\
\text { Perancangan }\end{array}$ & $\begin{array}{c}\text { Hasil } \\
\text { Perancangan }\end{array}$ \\
\hline 1 & Bahan Penstock & $\begin{array}{c}\text { Mild Steel } \\
\text { Galvanized }\end{array}$ \\
\hline 2 & Panjang Penstock & $54 \mathrm{~m}$ \\
\hline 3 & Diameter Penstock & $0,8272 \mathrm{~m}$ \\
\hline 4 & Tebal Penstock & $0,002 \mathrm{~m}$ \\
\hline 5 & Jumlah belokan & 2 belokan \\
\hline 6 & $\begin{array}{c}\text { Sudut belokan } \\
\text { pertama }\end{array}$ & $10^{\circ}$ \\
\hline 7 & $\begin{array}{c}\text { Sudut belokan } \\
\text { kedua }\end{array}$ & 2 katup \\
\hline 8 & Jumlah Katup & 1 katup \\
\hline 9 & Gate Valve & 1 katup \\
\hline 10 & Butterfly valve & 3 buah \\
\hline 11 & Jumlah Anchor & 11 buah \\
\hline 12 & Jumlah Slide block & \\
\hline
\end{tabular}

Data perhitungan setelah perancangan penstock. TABEL II

DATA PERHITUNGAN SETELAH PERANCANGAN PENSTOCK

M. Desain Penstock

Menurut perhitungan yang telah didapatkan maka dilakukan pendesainan penstock menggunakan aplikasi komputer. Berikut hasil desain penstock

p-ISSN:1693 - 2951; e-ISSN: 2503-2372 


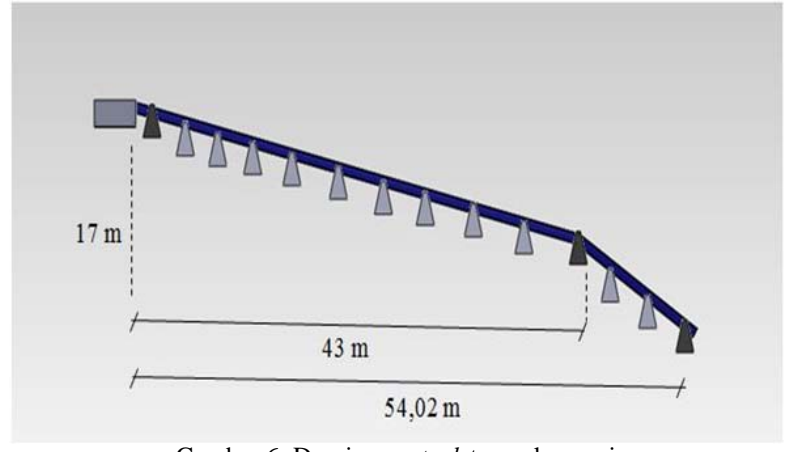

Gambar 6: Desain penstock tampak samping

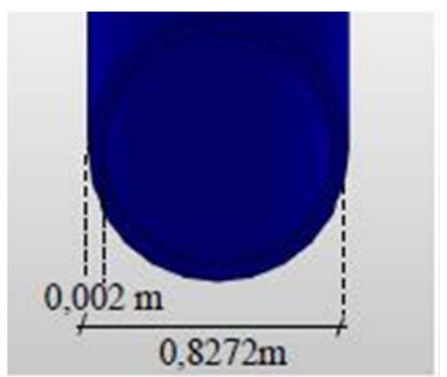

Gambar 7: Desain penstock tampak depan

\section{N. Desain Anchor Block}

Desain anchor block sebagai berikut.

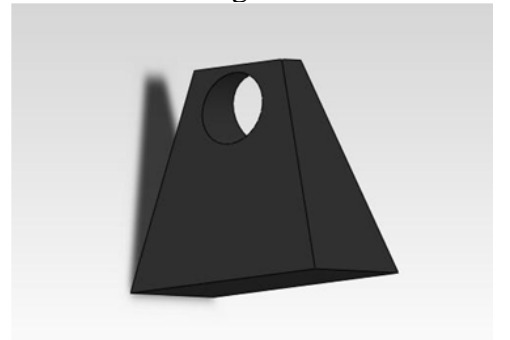

Gambar 8: Desain anchor block

\section{O. Desain Slide Block}

Desain slide block sebagai berikut.

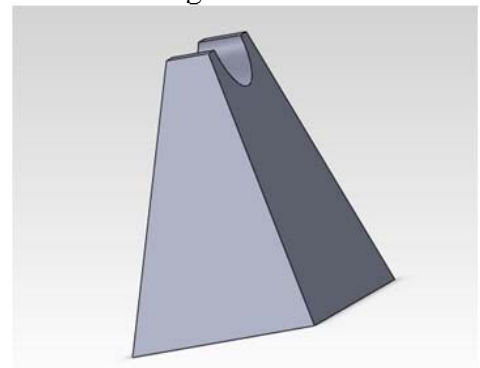

Gambar 9: Desain slider block

\section{KESIMPULAN}

Simpulan pada penelitian ini, bahan pembuatan penstock menggunakan baja berlapis. Penstock dengan panjang 54 m dengan 2 belokan, dan 3 buah anchor block, 11 slide block. Garis tengah penstock yaitu 0,8272 m dan 0,002 m tebalnya. Kecepatan aliran air di dalam penstock sebesar 2,7088 m/s. Expansion joint yaitu 7,72 mm dan 1,98 mm. Head gross $_{\text {sebesar } 17 \mathrm{~m} \text { dengan Head }}$ net sebesar 16 m. Surge pressure diperoleh $167,42 \mathrm{~m}$ dan rugi-rugi total yang terjadi pada penstock 184,42.

\section{REFERENSI}

[1]. PT. PLN (Persero). 2019. Rencana Usaha Penyediaan Tenaga Listrik (RUPTL) 2019 - 2028. Jakarta: Kementerian ESDM

[2]. Kementrian Energi Dan Sumber Daya Mineral. 2013. Statistik Energi Baru, Terbarukan Dan Konservasi Energi.

[3]. Jellyn Trissiana, 2019. Studi Potensi Pengembangan Pembangkit Listrik Tenaga Mikrohidro (PLTMH) di Kawasan Wisata Air Terjun Sumerwangi Desa Tirtomarto Kecamatan Ampelgading Kabupaten Malang

[4] Dedi Nugroho, Agus Suprajitno dan Gunawan, 2017. Desain Pembangkit Listrik Tenaga Mikrohidro di Air Terjun Kedung Kayang.

[5] I Wayan Budiarsana Saputra, Antonius Ibi Weking, dan Lie Jasa, 2017. Rancang Bangun Pemodelan Pembangkit Listrik Tenaga Mikrohidro (PLTMH) Menggunakan Kincir Overshot Wheel

[6] Mohammad Arief Rusdiono, Suwanto Marsudi, dan Prima Hadi Wicaksono 2018. Studi Perencanaan Pembangkit Listrik Tenaga Mikrohidro (PLTMH) di Saluran Primer Sindupraja Kabupaten Majalengka Provinsi Jawa Barat.

[7] Richiraj P Moni, Bijimol Joseph, Dangy George, and Jithin Jose, 2018. Design and Analysis of Anchor Block and Penstock Pipe of a Hydroelectric Project.

[8] Joko Susetyo, Imam Sodikin dan Taufik Narrohim, 2019. Usulan Pengendalian dan Perbaikan Kualitas Pengelasan Pipa Penstock Dengan Metode Six Sigma Seven Tools dan 4M+IE

[9] Harvey, Adam. 1993. Micro-Hydro Design Manual, Intermediate Technology Publications: London.

[10] L Hensley, 2018. Expansion Joint System.

[11] Dhimanssyah, 2017. Studi Literatur Expansion Joint. [Online]. Tersedia pada :

https://elib.unikom.ac.id/files/disk1/584/jbptunikompp-gdldhimassyah-29193-8-unikom_d-2.pdf

[12] Agus Sugiharto, 2018. PLTMH Sebagai Alternatif Pembangkit Listrik Ramah Lingkungan.

[13] D P D Suparyawan, I N S Kumara, dan W G Arisastina, 2013. Studi Perencanaan Pembangkit Listrik Mikrohidro di Desa Sambangan Kabupaten Buleleng Bali.

[14] K. Daniel Kristama Vika, Antonius Ibi Weking,dan Lie Jasa, 2018. Studi Analisis Pengaruh Posisi Nozzle Terhadap Pout Pada Prototipe PLTMH.

[15] I Gede Widnyana Putra, Antonius Ibi Weking, dan Lie Jasa, 2018. Analisa Pengaruh Tekanan Air Terhadap Kinerja PLTMH dengn Menggunakan Turbin Archimedes Screw.

[16] I Putu Juliana, Antonius Ibi Weking, dan Lie Jasa, 2018. Pengaruh Sudut Kemiringan Head Turbin Ulir dan Daya Putar Turbin dan Daya Output Pada Pembangkit Listrik Tenaga Mikro Hidro.

[17] Lie jasa, I Putu Ardana, Ardyono Priyadi, and Mauridhi Hery Purnomo, 2016. Investigate Curvature Angle of the Blade of Bangki's Water Model for Improving Efficiency by Means Particle Swarm Optimization.

[18]. Budi Hartadi, 2015. Perancangan Penstock, Runner dan Spiral Casing Pada Turbin Air Kaplan Untuk Pembangkit Listrik Tenaga Listrik Mikrohidro (PLTMH) Di Sungai Sampanahan Desa Magalau Hulu Kabupaten Kotabaru. Universitas Islam Kalimantan. Volume 1, No1.

[19]. Peraturan Presiden No. 22 Tahun 2017, Tentang Rencana Umum Energi Nasional

[20] Suryanto, dkk, 2019. Analisis Perancangan Penstock PLTMH di Eremerasa Kabupaten Bantaeng dengan Menggunakan ANSYS. Volume 17(1): 16-24. 